regrettable, but unavoidable until the inhabitants can be persuaded to take up their residence elsewhere.

The administration is faced with a constant conflict between the cultivator and the marauding elephant; this is a grave problem as the cultivator invariably uses his gun, generally inflicting wounds and making the animal a rogue. Several cases have been reported recently in which inhabitants have been attacked and killed by elephants. These animals have had to be officially proclaimed "rogues" and destroyed.

Elephants are animals of habit and will occupy traditional areas for their feeding, as their ancestors have done for generations. Many persuasive methods, such as burning fires, sounding sirens at night, electrical and wooden fences and lighting of crackers from watch huts, have been tried and are in use. Perhaps, before long, elephants will learn they must move to the safer confines of the national park and that their reign in the valley must come to an end.

This new reserve proves that irrigation schemes can benefit the protection of wild life if tackled in the right way, for natural cover of vegetation in the catchment areas is necessary for the success of the scheme itsclf.

I am greatly indebted to Dr. R. W. Szechowycz, the Board's Chief Forest Officer, for the information he supplied to enable me to compile this short article.

\title{
HOW A LEOPARD KILLS HIS PREY
}

\section{(Translations from reports of the staff of the Ceylon Wild Life Department)}

By Game Guard W. L. A. Andris of Yala Range

I was on my way to Yala one evening and, near Wilapalawewa, I noticed a leopard lying beneath a tree. I took cover and watched. The leopard was lying on its belly with its forelegs stretched forward and its gaze was fixed on a herd of spotted decr which was grazing about 100 yards away. It kept tossing its tail about but its head and body were motionless. The unsuspecting deer were nibbling the grass and moving slowly forward towards the lcopard. As they appronched closer and closer the leopard gradually brought its forclegs back close to its body and kept its head low down, but the occasional twitching of the tail continued. When the deer were within 20 yards the 
leopard became very tense and I knew that the charge was imminent. Suddenly, it shot forward like a streak and in a flash had seized a spotted doe. It attacked the doe from in front, threw its paws round the doc's neck, seized the doe by the throat with its jaws, and clung on. The rest of the herd ran some yards and then stopped and stood looking on, barking and stamping. The doomed doe stood its ground for some minutes while the leopard hung on and got its fangs deeper into its victim's throat. Then the doe collapsed and fell sideways. The leopard did not relax its hold but pressed the doe, which was kicking and making frantic efforts to rise, to the ground. Soon the doe lay still. The leopard then released its hold, moved off a few yards, sat on its haunches and looked at its fallen victim. Two or three times it sprang back on the doe and bit its neck, and again moved away and watched. Then the leopard seized the carcase of the doe by its neck, and dragged it, the carcase being parallel to the leopard's body, towards the tank. The herd of deer, which all the time remained 30 or 40 yards away, followed the leopard at a distance, still giving the shrill, alarm call.

\section{By Game IVatcher A. Malhamy of IVilpattu Range}

About 7 o'clock one morning, at the height of the drought, I saw a leopard about 150 yards away walking across the dry bed of the Maradanmaduwa tank. I followed cautiously, got under a tree and sat down to watch. The leopard had by then climbed up a Dan tree and lay down on a branch about 10 feet above ground. The Dan tree was in full fruit and every day deer and pigs used to come under it to eat the fallen berries. 'The leopard lay perfectly still on the branch of the trec, only turning its head to look all around. After about half an hour a small herd of 9 spotted decr came across the dry bed of the tank, stopping to nibble every now and again, towards the Dan tree. The leopard became absolutely still. The deer reached the tree and began to feed on the fallen fruit. One of the does came right under the branch on which the leopard was lying. I saw no movement of the leopard which was absolutely still and tense. Suddenly it sprang on the back of the doc beneath it. "The doe called out loudly but the leopard kept its hold and bit at the doe's throat, with each bite getting a firmer grip on its throat. At the doe's cries the rest of the herd stampeded for a short distance and then stood and barked violently and stamped the ground with their forefeet. 'The seized doe then fell to the ground. 'The leopard continued to bite the fallen doe's throat 
and to claw its body, the leopard's tail twitching and tossing from side to side all the time. The doe soon lay still and the leopard got off its kill, moved away 2 or 3 yards and sat on its haunches, panting and watching its kill. It sat thus for about 2 minutes and then got up and walked twice round the dead doe. Then it seized the carcase by the neck and walking backwards, dragged the carcase about 20 yards into scrub jungle and disappeared from view.

\section{By Game Guard W. L.'A. Andris of Yala Range}

One evening I was coming round Suduwelimulla when I saw a sounder of 8 adult pigs and 7 small sucklings feeding in a muddy pool. Almost at the same time I noticed a leopard emerge from the jungle edge. I concealed myself and watched. The leopard sat on its haunches and watched the pigs from a distance of about 150 yards for about 20 minutes. 'Then it rose and walked slowly and cautiously towards the pigs, which were in the hollow of the pool, till it was about 75 yards away when it lay down flat on its stomach with its head low. The pigs were now leaving the pool and moving towards the crouching leopard, unconscious of its presence. The leopard lay absolutely still, with only an occasional slow movement of its tail. The pigs moved closer to within about 25 feet when the leopard suddenly sprang out amongst them. In a moment it was out again, running full speed on three legs, with one suckling held in its mouth and another hooked in the claws of its right, front paw. It ran for about 75 yards and quickly went up a Malittan tree. The rest of the sounder of pigs pursued the leopard, grunting and screaming, but could not catch up with it. 'The suckling in the leopard's mouth appeared to be dead, but the other one in its paw was squealing loudly. The sounder reached the tree which the leopard had climbed and ran about, grunting, around the treefoot. Some pigs stood on their hind-quarters and bit the bark of the tree, making various noises. After a time there was silence and I left my hiding place and approached the tree. The pigs were still there and ran away on seeing me. The leopard was on the tree. It had killed both sucklings, placed one on a fork of the tree and was eating the other.

With acknowledgements to Loris, the Journal of the Wild Life Protection Socicty of Ceylon. 